\title{
Substitusi rumput lapang dengan hay African Star Grass (Cynodon plectostachyus) terhadap produktivitas kelinci lokal jantan
}

\section{Field grass substitution with hay African Star Grass (Cynodon plectostachyus) on productivity of local male rabbit}

\section{Syifa Nurjannah ${ }^{1 *}$, Ikhsan Kholiq ${ }^{1}$, Tedi Akhdiat1, Nilawati Widjaya ${ }^{1}$}

${ }^{1}$ Program Studi Peternakan, Fakultas Pertanian, Universitas Insan Cendekia Mandiri . Jl. Banten No.11, Kebonwaru, Batunung l, Kota Bandung, Jawa Barat 40272

*Email Koresponden: syifa.nurjannah21@gmail.com

\begin{tabular}{|c|c|}
\hline ARTICLE INFO & A B S T R A K \\
\hline Received: & Penelitian ini bertujuan untuk mengetahui substitusi rumput lapang oleh hay African \\
\hline 11 July 2021 & Star Grass (Cynodon plectostachyus) terhadap produktivitas kelinci lokal jantan umur \\
\hline Accepted: & tiga bulan. Penelitian dilaksanakan pada bulan Oktober-November 2020 di Kampung \\
\hline 27 October 2021 & Pojok Tengah, Cikahuripan, Lembang, Kabupaten Bandung Barat. Metode penelitian \\
\hline Published: & menggunakan Rancangan Acak Lengkap dengan lima perlakuan, yaitu P0: 80\% rumput \\
\hline 31 October 2021 & lapang $+20 \%$ konsentrat; P1: $60 \%$ rumput lapang $+20 \%$ hay African Star Grass $+20 \%$ \\
\hline & $\begin{array}{l}\text { konsentrat; P2: } 40 \% \text { rumput lapang }+40 \% \text { hay African Star Grass }+20 \% \text { konsentrat; } \\
\text { P3: } 20 \% \text { rumput lapang }+60 \% \text { hay African Star Grass }+20 \% \text { konsentrat; P4: } 80 \% \\
\text { hay African Star Grass }+20 \% \text { konsentrat, dan setiap perlakuan diulang sebanyak } \\
\text { lima kali sehingga jumlah kelinci yang digunakan sebanyak } 25 \text { ekor. Data yang }\end{array}$ \\
\hline Kata kunci: & diperoleh dianalisis menggunakan software SPSS dan uji jarak berganda Duncan. Hasil \\
\hline African Star grass & penelitian menunjukkan bahwa substitusi rumput lapang oleh hay African Star Grass \\
\hline Hay & mempengaruhi konsumsi ransum $(\mathrm{P}<0,05)$ dengan rata-rata antara $150,79-185,78$ \\
\hline Kelinci lokal jantan & gram/ekor/hari, tetapi tidak mempengaruhi pertambahan bobot badan dan konversi \\
\hline Produktivitas & ransum $(P>0,05)$ dengan rata-rata berturut-turut 14,64-19,78 gram/ekor/hari dan \\
\hline Rumput lapang. & $\begin{array}{l}\text { 7,94-11,60. Kesimpulan dari penelitian ini adalah pemberian hay African Star Grass } \\
\text { pada taraf } 20 \% \text { menunjukkan hasil yang lebih optimal. }\end{array}$ \\
\hline
\end{tabular}

\section{A B S T R A C T}

The purpose of this research was to determine field grass substitution by hay African Star Grass (Cynodon plectostachyus) on the productivity of local male rabbits with an age of 3 months old. The research was conducted in October-November 2020 in Central Pojok Village, Cikahuripan, Lembang, West Bandung Regency. The research method used a completely randomized design with five treatments which were P0: $80 \%$ field grass $+20 \%$ concentrate; $P 1: 60 \%$ field grass $+20 \%$ hay African Star Grass $+20 \%$ concentrate; $P 2: 40 \%$ field grass $+40 \%$ hay African Star Grass $+20 \%$ concentrate; P3: $20 \%$ field grass $+60 \%$ hay African Star Grass + 20\% concentrate; P4: 80\% African Star Grass hay + 20\% concentrate, and each treatment was repeated five times so that the number of rabbits used were 25

Key words: African Star grass Hay

Local male rabbit Productivity Field grass. heads. Data obtained were analyzed using SPSS software and Duncan's multiple range test. The results showed that the substitution of field grass by Afrikan Star Grass affected ration consumption $(P<0.05)$ with an average of 150.79-185.78 grams/head/day, but did not affect body weight gain and feed conversion $(P>0.05)$ with an average of 14.64-19.78 grams/head/day and 7.94-11.60, respectively. This study concluded that the provision of hay African Star Grass at the level of $20 \%$ showed more optimal results.. 


\section{PENDAHULUAN}

Seiring dengan meningkatnya kesejahteraan masyarakat, maka semakin tinggi kesadaran masyarakat terhadap kebutuhan gizi, khususnya kebutuhan protein hewani seperti daging. Kelinci merupakan salah satu ternak yang dapat menghasilkan daging berkualitas tinggi, akan tetapi daging kelinci belum begitu familiar dikalangan masyarakat umum. Pada umumnya kelinci hanya dijadikan sebagai ternak fancy atau ternak hias, namun menurut studi yang telah dilakukan, kelinci memiliki ciri khas lain, yaitu menghasilkan daging dengan kandungan gizi lebih baik dari daging ayam. Daging kelinci memiliki kandungan protein $21,20 \%$, lemak 9,20\%, serat $1,10 \%$, dan kolesterol 0,056\%, sedangkan daging ayam memiliki kandungan protein $20,10 \%$, lemak $10,80 \%$, serat $1,00 \%$, dan kolesterol $0,068 \%$ (Nistor et al., 2013).

Keberhasilan usaha peternakan ditentukan oleh banyak faktor. Selain dari pemilihan bibit dan tatalaksana pemeliharaan yang baik, pakan juga menjadi salah satu faktor yang dapat berpengaruh terhadap produktivitas ternak. Sampai saat ini peternak kelinci memberikan pakan hanya hijauan berupa rumput lapang, yang memiliki kandungan nutrien yang cukup rendah, yaitu kandungan bahan kering 27,66\%, protein kasar 4,21\%, lemak kasar 0,56\%, serat kasar 8,24\%, abu 3,80\%, kalsium 0,19\% dan fosfor 0,09\% (Dwinarto, Bogassara, A, Sunarwan, \& Anarudin, 2013). Kebutuhan nutrisi kelinci muda adalah protein kasar 16-18\% dan serat kasar 12-16\% (Peraturan Menteri Pertanian Republik Indonesia, 2014). Berdasarkan kebutuhan nutrisi kelinci pada masa pertumbuhan, rumput lapang tidak mencukupi kebutuhan, sehingga diperlukan penambahan atau substitusi rumput dengan pakan yang memiliki kualitas yang lebih baik.

Rumput African Star Grass dapat dijadikan sebagai salah satu pakan alternatif pada musim kemarau. Kelebihan dari rumput ini adalah produksi yang cukup tinggi, sekitar 47,0-55,6 ton/ha/tahun dalam bentuk segar serta memiliki kandungan nutrisi yang tinggi, yaitu bahan kering 29,61\%, protein kasar 15,34\%, lemak kasar 0,92\%, serat kasar 27,92\%, abu 9,20\%, kalsium 0,49\%, dan fosfor 0,24\% (Dwinarto et al., 2013), selain itu dapat tumbuh di daerah tropis. Salah satu ciri rumput African Star Grass adalah memiliki stolon atau batang yang lunak, sehingga sesuai apabila dijadikan sebagai hay.

Hay merupakan salah satu cara pengolahan pakan hijauan dengan cara dikeringkan. Pembuatan hay bertujuan untuk memanfaatkan kelebihan produksi hijauan pada saat musim hujan sehingga dapat disimpan dalam jangka waktu yang lama. Pemberian hay pada kelinci masih jarang dilakukan sehingga hal tersebut perlu dikembangkan lagi. Hay memiliki kandungan serat kasar yang cukup tinggi, tetapi hal tersebut tidak akan menimbulkan masalah yang signifikan. Kelinci memiliki sistem pencernaan yang sederhana dengan caecum dan usus yang besar yang memungkinkan kelinci untuk dapat memanfaatkan pakan hijauan, rumput dan sejenisnya yang kandungan seratnya tinggi (Nasution, Sembiring, \& Hamdan, 2015). Penelitian ini bertujuan untuk mengkaji substitusi rumput lapang oleh hay African Star Grass (Cynodon plectostachyus) terhadap produktivitas kelinci lokal jantan.

\section{MATERI DAN METODE}

\section{Materi}

Materi yang digunakan terdiri atas rumput lapang, konsentrat (dari KPSBU Jawa Barat, terdiri atas dedak, pollard, bungkil kelapa, bungkil sawit, ampas kecap, tongkol jagung, mineral, kalsium, sekam, menir, dan onggok), African Star Grass dengan umur panen kurang lebih 21 hari yang selanjutnya dibuat menjadi hay dengan panas matahari selama 2 sampai 3 hari sampai kandungan airnya kurang dari 20\% (menyesuaikan kondisi di lapangan). Komposisi nutrien bahan pakan penelitian dapat dilihat pada Tabel 1.

Tabel 1. Komposisi nutrien bahan pakan penelitian.

\begin{tabular}{lrrrc}
\hline \multirow{2}{*}{ Bahan Pakan } & \multicolumn{4}{c}{ Persentase (\%) } \\
\cline { 2 - 5 } & \multicolumn{1}{c}{ PK } & \multicolumn{1}{c}{ LK } & \multicolumn{1}{c}{ SK } & TDN \\
\hline Rumput Lapang & $3,80^{1}$ & $4,21^{1}$ & $0,56^{1}$ & $52,12^{2}$ \\
African Star Grass & $15,34^{1}$ & $0,92^{1}$ & $27,92^{1}$ & - \\
Konsentrat & $17,64^{2}$ & $10,64^{2}$ & $16,38^{2}$ & $74,09^{2}$ \\
\hline
\end{tabular}

Sumber: Dwinarto et al. (2013), Laboratorium Nutrisi Ternak Ruminansia dan Kimia Makanan Ternak Fakultas Peternakan, Universitas Padjajaran (2015)

Objek yang digunakan adalah kelinci lokal jantan umur tiga bulan sebanyak 25 ekor, dengan 
rata-rata bobot badan 863,57 gram/ekor dan koefisien variasi 3,91\%. Kelinci diperoleh dari bandar dan pengepul yang berada di daerah Cikahuripan, Lembang, Kabupaten Bandung Barat.

\section{Metode}

Penelitian dilaksanakan di kandang peternak yang bertempat di Kampung Pojok Tengah RT.05 RW.05, Desa Cikahuripan, Kecamatan Lembang, Kabupaten Bandung Barat pada bulan Oktober-November 2020 selama dua bulan, mulai dari persiapan, masa adaptasi, masa perlakuan, sampai dengan pengambilan data penelitian. Adaptasi ransum dilakukan selama tujuh hari, dilanjutkan dengan masa pemeliharaan yang diberi ransum sesuai perlakuan selama 35 hari. Ransum diberikan sesuai dengan kebutuhan ransum kelinci, yakni protein kasar $15-17 \%$, serat kasar $14 \%$, lemak kasar 3\%, kalsium $0,50-1,10 \%$, dan posfor 0,30 0,80\% (Lebas, 1983).

\section{Rancangan Penelitian dan Analisis Statistik}

Penelitian secara eksperimental menggunakan Rancangan Acak Lengkap dengan lima perlakuan dan lima ulangan, setiap ulangan menggunakan satu ekor kelinci sehingga jumlah ternak secara keseluruhan adalah 25 ekor. Kemudian data yang diperoleh diuji menggunakan menggunakan software Statistical Product and Service Solutions (SPSS) dan uji lanjut dengan Uji Jarak Berganda Duncan. Perlakuan terdiri atas: P0 (80\% rumput lapang + 20\% konsentrat); P1 (60\% rumput lapang + $20 \%$ hay African Star Grass + 20\% konsentrat);
P2 (40\% rumput lapang $+40 \%$ hay African Star Grass + 20\% konsentrat); P3 (20\% rumput lapang $+60 \%$ hay African Star Grass + 20\% konsentrat); P4 (80\% hay African Star Grass + $20 \%$ konsentrat). Persentase dan kandungan nutrien ransum penelitian dapat dilihat pada Tabel 2.

\section{Variabel yang Diamati \\ Konsumsi Ransum}

Konsumsi ransum kelinci merupakan banyaknya ransum yang dikonsumsi kelinci hasil dari pengurangan antara ransum yang diberikan dengan ransum sisa. Pemberian ransum dilakukan sebanyak dua kali, yakni pada pukul 07.30 WIB sebanyak 40\% dan pukul 16.00 WIB sebanyak $60 \%$ dari total ransum yang diberikan. Keesokan harinya sebelum diberikan ransum baru, terlebih dahulu dilakukan penimbangan sisa ransum. Konsumsi ransum dihitung dengan rumus sebagai berikut:

Konsumsi ransum = ransum awal - ransum sisa

\section{Pertambahan Bobot Badan Harian}

Pertambahan bobot badan harian kelinci dihasilkan dari adanya pengurangan antara bobot akhir dengan bobot awal dibagi lamanya pemeliharaan. Penimbangan dilakukan setiap satu minggu satu kali selama penelitian setiap pagi hari sebelum diberi ransum baru. Pertambahan bobot badan harian dihitung dengan rumus (Supratman, Setiyatwan, Budinuryanto, Fitriani, \& Ramdani, 2016) sebagai berikut:

PBBH $=($ BB Akhir - BB Awal) $/($ Lama Penelitian $)$

Tabel 2. Persentase dan kandungan nutrien ransum penelitian.

\begin{tabular}{lccccc}
\hline \multirow{2}{*}{ Bahan Pakan } & \multicolumn{5}{c}{ Persentase (\%) } \\
\cline { 2 - 6 } & P0 & P1 & P2 & P3 & P4 \\
\hline Rumput Lapang & 80,00 & 60,00 & 40,00 & 20,00 & 0,00 \\
African Star Grass & 0,00 & 20,00 & 40,00 & 60,00 & 80,00 \\
Konsentrat & 20,00 & 20,00 & 20,00 & 20,00 & 20,00 \\
Total & 100,00 & 100,00 & 100,00 & 100,00 & 100,00 \\
Kandungan Nutrien & & & & & \\
Protein Kasar & 6,57 & 8,88 & 11,18 & 13,49 & 15,80 \\
Lemak Kasar & 5,45 & 4,77 & 4,11 & 3,45 & 2,79 \\
Serat Kasar & 3,27 & 9,20 & 14,67 & 20,14 & 25,61 \\
\hline Keterangan Pen
\end{tabular}

Keterangan: Perhitungan berdasarkan metode trial and error 


\section{Konversi Ransum}

Konversi ransum merupakan perbandingan antara ransum yang dikonsumsi dengan pertambahan bobot badan harian yang dihasilkan. Tujuannya adalah untuk mengetahui efisiensi ternak dalam memanfaatkan ransum yang dikonsumsi. Konversi ransum dihitung dengan rumus (Supratman et al., 2016) sebagai berikut:

Konversi ransum $=$ Konsumsi ransum (gram/ ekor/hari )/PBBH (gram/ekor/hari )

\section{HASIL DAN PEMBAHASAN}

\section{Konsumsi Ransum}

Rata-rata konsumsi ransum penelitian dapat dilihat pada Tabel 3 yang menunjukkan rata-rata berkisar antara 150,79-185,78 gram/ ekor/hari. Rata-rata konsumsi ransum penelitian lebih besar dibandingkan penelitian Saputra et al., (2016) yang menggunakan kelinci lokal jantan yang diberi ransum berbasis limbah dan hijauan kelapa sawit dengan rataan konsumsi ransum antara 255,80-293,75 gram/ekor/ minggu atau setara dengan 36,54-41,96 gram/ ekor/hari.

Substitusi rumput lapang menggunakan hay African Star Grass sebanyak 20\% dalam ransum menghasilkan rata-rata konsumsi ransum tertinggi, sedangkan substitusi rumput lapang oleh hay African Star Grass secara keseluruhan menghasilkan rataan konsumsi terendah. Hasil analisis menunjukkan bahwa substitusi rumput lapang oleh hay African Star Grass sebanyak $20 \%$ nyata $(\mathrm{P}<0,05)$ mempengaruhi konsumsi ransum kelinci lokal jantan. Dilihat dari hasil analisis, pemberian hay pada level yang lebih tinggi dapat menurunkan konsumsi ransum kelinci. Semakin banyak konsumsi ransum maka asupan nutrien pada ternak semakin banyak sehingga mampu memenuhi kebutuhan hidup pokok. Jumlah konsumsi ransum menentukan banyaknya zat makanan yang masuk ke dalam tubuh ternak (Nurjannah, Ayuningsih, Hernaman, \& Susilawati, 2019).

Konsumsi ransum dapat dipengaruhi oleh kandungan serat kasar. Kelinci akan berhenti makan apabila saluran pencernaan dalam tubuh kelinci sudah penuh. Kandungan serat kasar perlakuan P3 dan P4 (Tabel 2) dalam ransum penelitian sangat tinggi, sedangkan kelinci hanya mentoleransi serat kasar $10-12 \%$ (Tilman et al., 1991). Salah satu fungsi serat kasar adalah sebagai pengisi perut, hal ini berarti apabila ransum memiliki kandungan serat kasar yang tinggi maka dapat menyebabkan rasa kenyang lebih lama (bulk) yang akan mengakibatkan konsumsi ransum menurun.

\section{Pertambahan Bobot Badan Harian (PBBH)}

Kenaikan bobot badan yang terjadi diakibatkan kelinci mampu mengubah nutrien yang terdapat pada ransum yang dikonsumsi menjadi daging dan lemak. Surya et al. (2021) menyebutkan bahwa pertambahan bobot badan merupakan indikator dari pertumbuhan ternak yang penting untuk diamati karena menggambarkan produksi daging yang diharapkan.

Pada Tabel 3 dapat dilihat bahwa ratarata $\mathrm{PBBH}$ masing-masing perlakuan berkisar 14,64-19,78 gram/ekor/hari. Rata-rata PBBH penelitian berada pada kisaran 10-20 gram/hari (Samkol \& Lukefahr, 2003), tetapi lebih besar dibandingkan Marhaeniyanto et al. (2015) yang menggunakan kelinci New Zealand White yang diberi daun kelor yang menghasilkan rata-rata PBBH antara 9,69-19,83 gram/ekor/hari.

Hasil analisis menunjukkan bahwa

Tabel 3. Produktivitas kelinci lokal jantan lepas sapih yang diberi ransum substitusi rumput lapang oleh hay African Star Grass.

\begin{tabular}{lccr}
\hline Perlakuan & $\begin{array}{c}\text { Konsumsi Ransum } \\
\text { (gram/ekor/hari) }\end{array}$ & $\begin{array}{c}\text { PBBH } \\
\text { (gram/ekor/hari) }\end{array}$ & Konversi Ransum \\
\hline P0 & $157,47 \pm 10,04 \mathrm{a}$ & $16,81 \pm 3,27$ & $9,68 \pm 1,79$ \\
P1 & $185,78 \pm 9,48 \mathrm{~b}$ & $17,99 \pm 3,86$ & $10,74 \pm 1,97$ \\
P2 & $156,20 \pm 5,90 \mathrm{a}$ & $19,78 \pm 1,33$ & $7,94 \pm 0,69$ \\
P3 & $153,84 \pm 4,20 \mathrm{a}$ & $15,20 \pm 4,43$ & $11,08 \pm 3,53$ \\
P4 & $150,79 \pm 10,01 \mathrm{a}$ & $14,64 \pm 4,46$ & $11,60 \pm 4,32$ \\
\hline
\end{tabular}

Keterangan: Huruf yang berbeda pada kolom yang sama menunjukkan perbedaan yang nyata $(\mathrm{P}>0,05)$ 
substitusi rumput lapang oleh hay African Star Grass tidak nyata $(\mathrm{P}>0,05)$ mempengaruhi pertambahan bobot badan harian kelinci lokal jantan. Hal ini menunjukkan bahwa ada atau tidaknya substitusi rumput lapang oleh hay African Star Grass tetap menghasilkan PBBH yang sama, tetapi penggunaan hay memberikan manfaat pada saat musim kemarau, pada saat ketersediaan ransum fluktuatif.

Salah satu faktor yang mempengaruhi PBBH adalah konsumsi ransum. Seperti dijelaskan Wahju (2004) semakin tinggi konsumsi ransum akan meningkatkan laju pertambahan bobot badan. Pendapat tersebut berbanding terbalik dengan konsumsi ransum yang dihasilkan pada penelitian. Pada penelitian ini konsumsi ransum yang tinggi tidak dapat menghasilkan pertambahan bobot badan yang tinggi juga. Hal ini dapat disebabkan salah satunya adalah fungsi saluran pencernaan pada kelinci lepas sapih belum mampu secara maksimal dalam mencerna dan memanfaatkan pakan tinggi serat (Tabel 2). Daya cerna kelinci lepas sapih mengkonsumsi hijauan sekitar 10\% (Sarwono, 2008).

Kelinci memiliki saluran pencernaan yang mirip dengan ternak ruminansia, akan tetapi kelinci tidak dapat mencerna serat kasar sebaik ternak ruminansia. Seperti dijelaskan Sarwono (2008) walaupun kelinci memiliki ceacum yang besar, kelinci ternyata tidak mampu mencerna bahan-bahan organik dan serat kasar dari pakan sebanyak ternak ruminansia. Kelinci termasuk ternak pseudoruminant hanya dapat memfermentasi pakan pada bagian usus belakang atau pada bagian caecum (bagian utama dari usus besar) yang memiliki kapasitas $50 \%$ dari total kapasitas saluran pencernaan kelinci.

Tingginya suhu lingkungan pada saat penelitian juga berpengaruh terhadap PBBH yang dihasilkan. Astuti et al. (2015) menyatakan perbedaan suhu lingkungan dapat menimbulkan cekaman stres sehingga menurunkan produksi. Selain itu rendahnya PPBH diakibatkan oleh ransum yang dikonsumsi memiliki kandungan nutrien yang masih kurang untuk kebutuhan kelinci tersebut. Sodikin, Erwanto, and Adhianto (2016), menyebutkan bahwa kenaikan bobot badan terjadi apabila pakan yang dikonsumsi telah melebihi kebutuhan hidup pokok.

\section{Konversi Ransum}

Surya et al. (2021), menyebutkan bahwa parameter yang dapat dijadikan gambaran untuk menilai efisiensi penggunaan ransum adalah nilai konversi ransum. Semakin rendah konversi ransum, menandakan penggunaan ransum yang semakin efisien. Rata-rata konversi ransum dapat dilihat pada Tabel 3 yang menunjukkan rata-rata perlakuan berkisar antara 7,94-11,60. Hasil analisis menunjukkan bahwa substitusi rumput lapang oleh hay African Star Grass tidak mempengaruhi konversi ransum $(\mathrm{P}>0,05)$ kelinci lokal jantan. Hal ini disebabkan efisiensi pemberiannya masih rendah karena level pemberian hay African Star Grass belum dapat meningkatkan nilai konversi meskipun konsumsi ransumnya meningkat.

Sama halnya dengan PBBH, konversi ransum pada setiap perlakuan memiliki hasil yang sama, akan tetapi apabila dilihat dari nilai rata-rata konversi ransum terendah ke tertinggi dihasilkan perlakuan P2 $(7,94), \quad$ P0 (9,68), P1 (10,74), P3 (11,08), dan P4 $(11,60)$. Rata-rata konversi ransum penelitian lebih kecil dibandingkan penelitian Saputra et al. (2016) yang menggunakan kelinci lokal jantan yang diberi ransum berbasis limbah dan hijauan kelapa sawit dengan rata-rata konversi ransum antara 11,07-12,55.

Semakin rendah nilai konversi maka semakin efisien ransum yang diberikan untuk mendapatkan pertumbuhan yang diinginkan, sebaliknya semakin tinggi nilai konversi ransum maka semakin tidak efisien pertumbuhan kelinci tersebut. Nilai konversi ransum dapat dipengaruhi oleh konsumsi ransum dan PBBH. Marhaeniyanto \& Susanti (2011) menjelaskan semakin baik kualitas ransum yang dikonsumsi kelinci, semakin efisien penggunaannya, akan diikuti oleh nilai PBBH yang makin tinggi. Bell \& Weaver (2002) menambahkan bahwa konversi ransum juga dipengaruhi oleh beberapa faktor diantaranya adalah tingkat stress pada ternak, penyakit ternak, cara dan waktu pemberian pakan, air, pencahayaan, temperatur, kebisingan sekitar kandang, bentuk fisik ransum, dan faktor anti nutrisi dari dalam bahan pakan tersebut.

\section{KESIMPULAN}

Substitusi rumput lapang oleh hay African Star Grass memberikan pengaruh nyata terhadap 
konsumsi ransum, namun tidak memberikan pengaruh pada pertambahan bobot badan harian dan konversi ransum. Berdasarkan konsumsi ransum, pemberian hay African Star Grass pada taraf $20 \%$ memberikan hasil yang paling optimal. Pemberian hay sebanyak 40\%, 60\%, dan $80 \%$ memiliki kandungan serat kasar yang cukup tinggi sehingga menyebabkan efek bulk yang membuat konsumsi menjadi sedikit dan pertambahan bobot badan menjadi lambat.

\section{DAFTAR PUSTAKA}

Astuti, A., Erwanto, \& E S, P. (2015). Pengaruh cara pemberian konsentrat-hijauan terhadap respon fisiologis dan performa sapi Peranakan Simmental. Jurnal Ilmiah Peternakan Terpadu, 3 (November), 201-207. https://doi.org/http://dx.doi. org/10.23960/jipt.v3i4.p\%25p

Bell, D. D., \& Weaver, W. D. (2002). Commercial Chicken Meat and Egg Production. New York: Springer Science \& Business.

Dwinarto, B., Bogassara, E., A, A. W., Sunarwan, \& Anarudin, I. (2013). Buku Hasil Uji Bahan Pakan dan Hijauan Pakan Ternak. Bekasi: Bahan Pengujian Mutu dan Sertifikasi Pakan Bekasi.

Lebas, F. (1983). Small Scale Rabbit Prudiction Feeding and Management System. Roma: World Animal Review.

Marhaeniyanto, E., Rusmiwari, S., \& Susanti, S. (2015). Pemanfaatan daun kelor untuk meningkatkan produksi ternak kelinci New Zealand White. Buana Sains, 15(2), 119126. https://doi.org/doi.org/10.33366/ bs.v15i2.369

Marhaeniyanto, E., \& Susanti, S. (2011). Strategi suplementasi leguminosa untuk meningkatkan penampilan domba. Buana Sains, 11(1), 7-16. https://doi.org/doi. org/10.33366/bs.v11i1.174

Nasution, F. A., Sembiring, I., \& Hamdan. (2015). Kecernaan kulit daging buah kopi dengan fermentasi mol ( mikroorganisme lokal ) dalam ransum pelet pakan kelinci peranakan rex. Jurnal Peternakan Integratif, 3(3), 319-328. https://doi.org/ https://doi.org/10.32734/jpi.v3i3.2767

Nistor, E., Bampidis, V., Pacala, N., Pentea, M., Tozer, J., \& Prundeanu, H. (2013). Nutrient content of rabbit meat as compared to chicken, beef and pork meat. Journal of Animal Production Advances, 3(4), 172176. https://doi.org/doi.org/10.5455/ JAPA.20130411110313
Nurjannah, S., Ayuningsih, B., Hernaman, I., \& Susilawati, I. (2019). Penggunaan kaliandra (Calliandra calothyrsus), Indigofera sp. dan campurannya dalam ransum sebagai pengganti konsentrat terhadap produktivitas Domba Garut jantan. Jurnal Ilmiah Peternakan Terpadu, 7(3), 293-298. https://doi.org/http:// dx.doi.org/10.23960/jipt.v7i3.p293-298

Peraturan Menteri Pertanian Republik Indonesia. (2014). Pedoman Budi Daya Kelinci yang Baik.

Samkol, P., \& Lukefahr, S. D. (2003). A Challenging Role for Organic Rabbit Production Towards Poverty Alleviation In South East Asia. 1479-1498. Verona, Italy: 9 th World Rabbit Congress.

Saputra, D. I., Liman, \& Muhtarudin. (2016). Pengaruh penambahan jenis pakan sumber protein pada ransum berbasis limbah dan hijauan kelapa sawit terhadap konsumsi, pertambahan bobot, dan efisiensi kelinci lokal jantan. Jurnal Ilmiah Peternakan Terpadu, 4(2), 170-175. https://doi.org/ dx.doi.org/10.23960/jipt.v4i2.p\%25p

Sarwono, B. (2008). Kelinci Potong dan Hias. Jakarta: Agromedia Pustaka.

Sodikin, A., Erwanto, \& Adhianto, K. (2016). Pengaruh penambahan multi nutrient sauce pada ransum terhadap pertambahan bobot badan harian sapi potong. Jurnal Ilmiah Peternakan Terpadu, 4(3), 199-203. https://doi.org/http://dx.doi. org/10.23960/jipt.v4i3.p\%25p

Supratman, H., Setiyatwan, H., Budinuryanto, D. C., Fitriani, A., \& Ramdani, D. (2016). Pengaruh imbangan hijauan dan konsentrat pakan komplit terhadap konsumsi, pertambahan bobot badan dan konversi pakan domba. Jurnal Ilmu Ternak, 16(1), 31-35. https://doi.org/doi. org/10.24198/jit.v16i1.9822

Surya, A., Suryanah, S., Widjaya, N., \& Permana, H. (2021). Pengaruh Pemberian Campuran Fermentasi Ampas Tahu dan Dedak Padi dalam Ransum terhadap Performa Bebek Pedaging Hibrida. Composite: Jurnal Ilmu Pertanian, 3(01), 17-24. https://doi. org/10.37577/composite.v3i01.302

Wahju, J. (2004). Ilmu Nutrisi Unggas. Yogyakarta: Gadjah Mada University Press. 